Огляди літератури, оригінальні дослідження, погляд на проблему, ювілеї

УДК 616.8-009.7+616.748-007.234]-02:616.728.3

DOI 10.11603/1811-2471.2018.v0.i2.8904

\title{
СУГЛОБОВИЙ БІЛЬ ПРИ ПЕРВИННОМУ ГОНАРТРОЗІ У ЛЮДЕЙ ПОХИЛОГО ВІКУ: ШЛЯХИ ПІДВИЩЕННЯ ЕФЕКТИВНОСТІ РЕАБІЛІТАЦІї
}

\author{
๑Т. Г. Бакалюк, І. Р. Мисула, Г. О. Сірант, Ю. В. Завіднюк, О. Я. Зятковська
}

ДВНЗ «Тернопільський державний медичний університет імені І. Я. Горбачевського МОз України»

РЕЗЮМЕ. Джерелом болю при остеоартрозі (ОА) можуть бути хрящова тканина, синовіальна мембрана, субхондральна кістка і періартикулярні тканини. Корекція всіх провідних ланок патогенезу ОА за допомогою лікарських засобів $\epsilon$ недостатньою, а шляхи підвищення ефективності лікування названого захворювання пов'язані із застосуванням методів, здатних впливати на механізми як патогенезу, так і саногенезу. Все це $\epsilon$ спонукальним моментом пошуку шляхів підвищення ефективності реабілітації.

Мета роботи - дослідити ефективність застосування об'ємного пневмопресингу (ОПП) в амбулаторних умовах у хворих на первинний гонартроз (ПГА) похилого віку.

Матеріал і методи. Клінічні спостереження проведені у 47 пацієнтів з ПГА віком від 60 до 74 років $((64,8 \pm 0,4)$ р.), які проходили амбулаторний етап реабілітації. Методом рандомізації хворі були поділені на дві групи. Реабілітаційний комплекс відрізнявся застосуванням в одній з груп ОПП на нижні кінцівки.

Результати. За даними реовазографічних досліджень у пацієнтів з ПГА після проведеного реабілітаційного комплексу із застосуванням ОПП встановлено прискорення гемодинаміки ( $<0,05)$, а за даними артросонографіїзменшення кількості надлишкової рідини в тканинах суглоба. Також встановлено достовірне $(p<0,05) 3$ зеншення больового синдрому, покращення функціональної активності суглобів та фізичної працездатності.

Висновки. На основі отриманих результатів запропоновано застосування в програмі реабілітації хворих на ПГА об'ємного пневмопресингу, який сприяє нормалізації функціонального стану рефлекторно змінених м'язів, активує місцевий кровообіг та зменшує венозний стаз. Реабілітаційний комплекс з включенням ОПП дозволяє підвищити ефективність проведених відновлювальних заходів на амбулаторному етапі реабілітації у хворих похилого віку з ПГА.

КЛючОВІ СлОВА: первинний гонартроз; больовий синдром; реабілітація; об'ємний пневмопресинг.

Вступ. Остеоартроз (ОА) є одним з найпоширеніших захворювань опорно-рухового апарату, особливо у осіб старшої вікової групи (у кожної третьої літньої людини, досягаючи 70 \% серед осіб старше 65 років) [3].

Больовий синдром при ОА у більшості випадків пов'язаний з дегенеративними процесами, що перебігають у хрящовій тканині, наявністю крайових кісткових розростань, капсулярного фіброзу, м'язової атрофії, синовіальної гіперплазії та синовіту [2,3]. Тобто, джерелом болю при ОА можуть бути хрящова тканина, синовіальна мембрана, субхондральна кістка і періартикулярні тканини.

У клінічний практиці часто доводиться стикатися з хронічним больовим синдромом при первинному гонартрозі (ПГА), обумовленому позасуглобовими патогенетичними механізмами. Наростаючі позасуглобові зміни при ПГА є реалізацією складного комплексу компенсаторно-пристосувальних реакцій. При цьому найчастішим пусковим механізмом болю стають анатомо-функціональні та біомеханічні невідповідності. Особливо чутливими до будь-яких внутрішніх та зовнішніх негативних впливів на суглоб $є$ м'язи, які безпосередньо його оточують $[6,8,9]$.

За даними багатьох дослідників $[7,10]$, розлади пропріоцептивної імпульсації приводять до зниження тонусу параартикулярних м'язів, i, як наслідок - до посилення механічного навантаження на суглоб.

3 віком відбувається зменшення м'язової сили та витривалості багатьох м'язових груп і тому розвиток ОА, особливо колінних суглобів, може спричинити подальше зниження цих параметрів та призвести до функціональних порушень [5].

Підсумовуючи вищенаведені літературні дані, які висвітлюють сучасні погляди на патогенез ОА, слід підкреслити їх суперечливість, невирішеність багатьох питань синергічної або антагоністичної взаємодії порушень різних рівнів регуляції та ланок, які складають основу механізму розвитку ОА. Зрозуміло також, що корекція всіх провідних ланок патогенезу ОА за допомогою лікарських засобів $\epsilon$ нереальною, а шляхи підвищення ефективності лікування названого захворювання пов'язані з подальшим пошуком чинників, здатних індивідуально активувати механізми виходу із хвороби, тобто механізми саногенезу, шляхом одночасного комплексного впливу на стан основних гомеостатичних систем організму (нейроендокринної, імунної, видільної, кровообігу).

На сьогоднішній день для хворих на ОА використовують великий арсенал методів медичної реабілітації, який постійно поповнюється. Одним із таких методів $є$ об'ємний пневмопресинг (ОПП), 
Огляди літератури, оригінальні дослідження, погляд на проблему, ювілеї

вплив якого $є$ багаторівневим, починаючи від подразнення шкірних рецепторних полів відповідних рефлексогенних зон до механічного впливу на глибоко розміщені тканини, що викликає каскад цілеспрямованих екстеро-та інтерорецептивних рефлексів. Активне спонукання току рідини спочатку в поверхневих, а потім у глибоко розміщених артеріальних, венозних та лімфатичних судинах, а також міжтканинної рідини сприяє інтенсифікації обмінних процесів у тканинах [4].

У зв'язку з відсутністю досліджень про застосування ОПП у людей похилого віку з ПГА для оптимізації реабілітаційних заходів в амбулаторних умовах ми застосували метод ОПП.

Мета роботи - обґрунтування та дослідження ефективності застосування об'ємного пневмопресингу в амбулаторних умовах у хворих на первинний гонартроз в похилому віці.

Матеріал і методи дослідження. Для реалізації поставленої мети ми обстежили 47 хворих на ПГА віком від 60 до 74 років, які перебували на амбулаторному етапі реабілітації. Середній вік хворих склав $(64,8 \pm 0,4)$ роки, жінок було 31 (66 \%), чоловіків- 16 (34\%). Тривалість захворювання становила від 4 до 14 років, в середньому $(7,4 \pm 0,2)$ р. Рентгенологічну стадію ОА встановлювали за класифікацією Kellgren J. N. i Lawrence J. S. (I ст. - 8 хворих, II ст. - 39 хворих). Критеріями включення були рівень болю за шкалою ВАШ не більше 60 мм, клініко-рентгенологічна стадія ОА не вище II, функціональна недостатність суглобів I-ІІ ст.

Методом рандомізації пацієнти були поділені на дві групи. Відчутної різниці за основними вихідними клініко-функціональними показниками між групами не виявлено. Всі пацієнти отримували реабілітаційний комплекс, який включав інтерференцтерапію на колінні суглоби № 8, аплікації гальваноболота температурою $28-30{ }^{\circ} \mathrm{C}$ № 8, вправи ПІР № 8. Схема лікування між групами відрізнялася наявністю в II групі $(n=27)$ ОПП (методика здійснювалась за допомогою апарата БІО-2, на нижній кінцівці щільно закріплювали пневмоманжету, режим переміщення пневмохвилі двосторонній, тривалість - 12 хвилин, курс лікування - 10 сеансів).

Для оцінки ступеня вираженості болю в суглобах ми використовували візуальну аналогову шкалу (ВАШ), а для характеристики функціональних порушень - опитувальник Western Ontario and McMaster Universities (WOMAC). Для визначення функціональної сили м'язів нижньої кінцівки використовували тест Ловетта. Ми відображали силу м'язів у процентах: $0=0 \%, 1=10 \%, 2=$ $25 \%, 3=50 \%, 4=75 \%, 5=100 \%$.

Алгоритм обстеження хворих, окрім клінічних методів та опитувальника WOMAC, включав проведення артросонографії, гоніометрії, реовазографії та, залежно від супутньої патології, додаткові методи дослідження.

Статистичну обробку результатів проводили за допомогою програми «Statistica - 10,0». Для оцінки значущості статистичних відмінностей між досліджуваними групами за відсутності нормального розподілу проводили порівняння груп за непараметричним ранговим критерієм КраскелаУоліса, з подальшим попарним тестуванням за критерієм Манна-Уїтні. Вірогідними вважали відмінності при ступені ймовірності безпомилкового прогнозу (p) $95 \%(p<0,05)$.

Результати й обговорення. За даними реовазографічних (РВГ) досліджень у обстежених паці$\epsilon$ нтів з ПГА виявлено різною мірою знижені кровонаповнення тканин суглоба та пружно-еластичні властивості магістральних судин, підвищення периферійного судинного опору, утруднення венозного відтоку. При цьому установлено, що основною діагностично значимою зміною в показниках РВГ $\epsilon$ підвищення омічного опору тканин колінного суглоба. У $(58 \pm 2,6)$ \% пацієнтів з I клініко-рентгенологічною стадією ПГА реєстрували лише ознаки вазоконстрикції, у 100 \% пацієнтів з ІІ стадією, за даними РВГ колінного суглоба, реєстрували зниження пружно-еластичних властивостей артерій, підвищення периферійного судинного опору та утруднення венозного відтоку. Периферійний кровообіг також страждав внаслідок дефіциту пульсового кровонаповнення і підвищення тонусу судин. Про це свідчило зменшення амплітуди реографічної хвилі, збільшення часу анакротичної фази та їі відношення до тривалості усієї хвилі $(P<0,05)$.

Як свідчать дані, наведені в таблиці 1, після проведеної реабілітації в II групі динаміка реографічних показників, а саме швидкість кровотоку, опір судин та венозний відтік, статистично достовірно змінювалась, що свідчило про покращення локального кровотоку під впливом ОПП.

Згідно з даними, наведеними в таблиці 2, після завершення амбулаторного лікування в групах пацієнтів із застосуванням у реабілітаційному комплексі ОПП (порівняно з пацієнтами I групи) достовірно покращувалися рухова активність та фізична працездатність, зменшувався ступінь вираження больового синдрому $(p<0,05)$. На осо6ливу увагу заслуговує зменшення ширини верхнього завороту у 18 пацієнтів з ознаками синовіту в II групі на $42 \%(p<0,05)$.

Сукупний аналіз регресу клінічної симптоматики та динаміки змін об'єктивних показників клінічних методів дослідження дозволив оцінити терапевтичну ефективність застосування ОПП.

Вплив ОПП на мікроциркуляторну систему приводить до значного прискорення гемодинамі- 
Огляди літератури, оригінальні дослідження, погляд на проблему, ювілеї

Таблиця 1. Динаміка реографічних показників у обстежених пацієнтів з ПГА при проходженні амбулаторного етапу реабілітації

\begin{tabular}{|c|c|c|c|c|}
\hline \multirow[t]{2}{*}{ Показник } & \multicolumn{2}{|c|}{$\begin{array}{l}\text { I група } \\
(n=20)\end{array}$} & \multicolumn{2}{|c|}{$\begin{array}{c}\text { II група } \\
(n=27)\end{array}$} \\
\hline & до лікування & після лікування & до лікування & після лікування \\
\hline $\begin{array}{l}\text { РСl, відн. од. } \\
\text { (min } 0,650)\end{array}$ & $0,540 \pm 0,209$ & $0,585 \pm 0,017^{a}$ & $0,524 \pm 0,021$ & $0,593 \pm 0,015^{a}$ \\
\hline $\begin{array}{l}\text { ЧПР, с } \\
(0,090-0,125)\end{array}$ & $0,146 \pm 0,001$ & $0,140 \pm 0,001^{\mathrm{a}}$ & $0,145 \pm 0,001$ & $0,135 \pm 0,001^{a}$ \\
\hline $\begin{array}{l}\text { чШН, c. } \\
(0,050-0,065)\end{array}$ & $0,074 \pm 0,001$ & $0,067 \pm 0,001^{a}$ & $0,072 \pm 0,001$ & $0,056 \pm 0,001^{\mathrm{ab}}$ \\
\hline $\begin{array}{l}\text { ПТК, од. } \\
(5,2-6,2)\end{array}$ & $6,700 \pm 0,040$ & $6,400 \pm 0,090^{\mathrm{a}}$ & $6,700 \pm 0,040$ & $6,280 \pm 0,0520^{\mathrm{a}}$ \\
\hline $\begin{array}{l}\text { ДІ, \% } \\
(60)\end{array}$ & $66,750 \pm 0,460$ & $64,930 \pm 0,470^{\text {a }}$ & $66,760 \pm 0,380$ & $62,590 \pm 0,410^{a b}$ \\
\hline $\begin{array}{l}\text { ПВВ, од. } \\
(0,80-0,30)\end{array}$ & $0,280 \pm 0,050$ & $0,310 \pm 0,010^{a}$ & $0,250 \pm 0,030$ & $0,520 \pm 0,490^{\mathrm{ab}}$ \\
\hline
\end{tabular}

Примітки: 1. а - різниця показника статистично значуща $(p<0,05)$ до і після лікування в межах групи;

2. b_ різниця показника статистично значуща $(p<0,05)$ після лікування між групами.

Таблиця 2. Динаміка функціональних показників у обстежених пацієнтів з ПГА при проходженні амбулаторного етапу реабілітації

\begin{tabular}{|c|c|c|c|c|}
\hline \multirow[t]{2}{*}{ Показник } & \multicolumn{2}{|c|}{$\begin{array}{c}\text { I група } \\
(n=20)\end{array}$} & \multicolumn{2}{|c|}{$\begin{array}{c}\text { II група } \\
(\mathrm{n}=27)\end{array}$} \\
\hline & до лікування & після лікування & до лікування & після лікування \\
\hline Біль в суглобах за ВАШ, бали & $54,16 \pm 1,12$ & $40,36 \pm 0,89^{a}$ & $58,17 \pm 1,27$ & $35,43 \pm 1,14^{a b}$ \\
\hline Сумарний індекс WOMAC, бали & $56,12 \pm 0,61$ & $42,88 \pm 0,44^{a}$ & $58,41 \pm 0,94$ & $34,30 \pm 0,65^{a b}$ \\
\hline Тест Ловетта, \% & $44,00 \pm 2,98$ & $54,00 \pm 2,50^{a}$ & $42,32 \pm 3,30$ & $61,22 \pm 3,05^{a}$ \\
\hline 06'єм рухів у суглобах, град. & $113,43 \pm 1,88$ & $135,84 \pm 1,91^{\text {a }}$ & $118,32 \pm 1,76$ & $146,37 \pm 1,95^{\mathrm{ab}}$ \\
\hline
\end{tabular}

ки, ліквідації ішемії суглобових тканин, зменшення больового синдрому, видалення надлишкової рідини із тканин суглоба. Також ОПП сприяє відновленню функції м'язів та сухожиль, збільшенню об'єму рухів у суглобі.

Враховуючи коморбідність у похилому віці і провідну роль ураження серцево-судинної системи, застосування ОПП є оптимальним методом системного фізіотерапевтичного впливу і може застосовуватись як для оптимізації програм реабілітації, так і у вигляді монотерапії.

Висновки. 1. Позитивна дія методу ОПП у пацієнтів з ПГА обумовлена зменшенням гіпоксії тканин у результаті активації місцевого кровообі-

\section{ЛІТЕРАТУРА}

1. Особенности функционирования мышц нижних конечностей и их спинальных центров при гонартрозах / А. М. Еремеев, А. А. Трофимова, И. И. Шайхутдинов [и др.] // Практическая медицина. - 2011. - № 7 (55). - С. 64-68.

2. Есин Р. Г. Боль: принципы терапии, боль в мануальной медицине : рук. для врачей / Р. Г. Есин. - Казань : Алма-лит, 2007. - 156 с. : ил. гу, зменшенням венозного стазу, нормалізацією функціонального стану рефлекторно змінених м'язів.

2. Застосування ОПП на амбулаторному етапі реабілітації у хворих похилого віку на ПГА дозволяє підвищити ефективність проведених відновлювальних заходів, зменшити і запобігти інвалідизації хворих, поліпшити їх якість життя, що має велике соціальне значення.

Перспективи подальших досліджень. 3 огляду на важливість проблеми плануємо вивчити комплексний вплив об'ємного пневмопресингу на суглоби та рефлекторно-сегментарні зони при остеоартрозі.

3. Коваленко В. Н. Остеоартроз : практическое руководство / В. Н. Коваленко, О. П. Борткевич. - Киев : Морион, 2010. - 601 с.

4. Бабова І. К. Метод об'ємного пневмопресингу: від витоків до сьогодення / І. К. Бабова, Т. В. Єльчиць, Д. В. Зайцев // Медична реабілітація, курортологія, фізіотерапія. - 2013. - № 4. - С. 34-37. 
Огляди літератури, оригінальні дослідження, погляд на проблему, ювілеї

5. Поворознюк В. В. Остеоартроз / В. В. Поворознюк // Мистецтво лікування. - 2004. - № 3. - С. 16-23.

6. Шостак Н. А. Клинические варианты остеоартроза - подходы к терапии / Н. А. Шостак, Н. Г. Правдюк, А. А. Клименко // Русский медицинский журнал. 2011. - T. 19, № 2. - С. 93-97.

7. Role of muscle in the genesis and management of knee osteoarthritis / K. L. Bennell, M. A. Hunt, T. V. Wrigley [et al.] // Rheum. Dis. Clin. North Am. - 2008. - No. 34 (3). P. 731-754.

\section{REFERENCES}

1. Eremeev, A.M., Trofimova, A.A., Shaykhutdinov, I.I., Zagidullin, M.V., \& Valeev, I.A. (2011). Osobennosti funktsionirovaniya myshts nizhnikh konechnostey i ikh spinalnykh tsentrov pri gonartrozakh [Features of the functioning of the muscles of the lower extremities and their spinal centers in gonarthrosis]. Prakticheskaya meditsyna Practical Medicine, 7 (55), 64-68 [in Russian].

2. Esin, R.H. (2007). Bol: printsipy terapii, bol v manualnoy meditsine: ruk. dlya vrachey [Pain: principles of thera$p y$, pain in manual medicine: guidelines for doctors]. Kazan: Alma-lit [in Russian].

3. Kovalenko, V.N., \& Bortkevich, O.P. (2010). Osteoartroz: prakticheskoye rukovodstvo [Osteoarthritis: a practical guide]. Kiev: Morion [in Ukrainian].

4. Babova, I.K., Yelchits T.V., \& Zaitsev D.V. (2013). Metod obiemnoho pnevmopresynhu: vid vytokiv do siohodennia [Method of volume pneumopressing: from the origins to the present]. Medychna reabilitatsiya, kurortolohiia, fizioterapiia - Medical Rehabilitation, Spa Therapy, Physiotherapy, 4, 34-37 [in Ukrainian].
8. Gallagher R. M. Chronic pain: sources of late life pain and risk factor for disability / R. M. Gallagher // Geriatrics. - 2005. - Vol. 55. - P. 40-47.

9. Knee extensor muscle weakness is a risk factor for development of knee osteoarthritis. A systematic review and meta-analysis / B. E. Oiestad, C. B. Juhl, I. Eitzen, J. B. Thorlund // Osteoarthritis Cartilage. - 2014. - P. 1305-1308.

10. Muscle weakness, afferent sensory dysfunction and exercise in knee osteoarthritis / E. M. Roos, W. Herzog, J. A. Block, K. L. Bennell // Nat. Rev. Rheumatol. - 2011. No. 7 (1). - P. 57-63.
5. Povorozniuk, V.V. (2004). Osteoartroz [Osteoarthritis]. Mystetstvo likuvannia - Art of Treatment, 3, 16-23 [in Ukrainian].

6. Shostak, N.A., Pravdiuk, N.H., \& Klimenko, A.A. (2011). Klinicheskiye varianty osteoartroza - podkhody $\mathrm{k}$ terapii [Clinical variants of osteoarthritis - approaches to therapy]. Russkiy meditsinskiy zhurnal - Russian Medical Journal, 9 (2), 93-97 [in Russian].

7. Bennell, K.L., Hunt, M.A., Wrigley, T.V., Lim, B.W., \& Hinman, R.S. (2008). Role of muscle in the genesis and management of knee osteoarthritis. Rheum. Dis. Clin. North Am., 34 (3), 731-754.

8. Gallagher, R.M. (2005). Chronic pain: sources of late life pain and risk factor for disability. Geriatrics, 55, 40-47.

9. Oiestad, B.E., Juhl, C.B., Eitzen, I., \& Thorlund, J.B. (2014) Knee extensor muscle weakness is a risk factor for development of knee osteoarthritis. A systematic review and meta-analysis. Osteoarthritis Cartilage, 1, 1305-1308.

10. Roos, E.M., Herzog, W., Block, J.A., \& Bennell, K.L. (2011). Muscle weakness, afferent sensory dysfunction and exercise in knee osteoarthritis. Nat. Rev. Rheumatol., 7 (1), 57-63.

\title{
СУСТАВНАЯ БОЛЬ ПРИ ПЕРВИЧНОМ ГОНАРТРОЗЕ У ПОЖИЛЫХ ЛЮДЕЙ: ПУТИ ПОВЫШЕНИЯ ЭФФЕКТИВНОСТИ РЕАБИЛИТАЦИИ
}

\author{
○Т. Г. Бакалюк, И. Р. Мисула, Г. О. Сирант, Ю. В. Завиднюк, Е. Я. Зятковская
}

ГВУз «Тернопольский государственный медицинский университет имени И. Я. Горбачевского МЗ Украчны»

РЕЗЮМЕ. Источником боли при остеоартрозе (ОА) могут быть хрящевая ткань, синовиальная мембрана, субхондральная кость и периартикулярные ткани. Коррекция всех ведущих звеньев патогенеза ОА с помощью лекарственных средств недостаточна, а пути повышения эффективности лечения названного заболевания связаны с применением методов, способных влиять на механизмы как патогенеза, так и саногенеза. Все это является побудительным моментом поиска путей повышения эффективности реабилитации.

Цель работы - исследовать эффективность применения объемного пневмопрессинга (ОПП) в амбулаторных условиях у больных первичным гонартрозом (ПГА) в пожилом возрасте.

Материал и методы. Клинические наблюдения проведены у 47 пациентов с ПГА в возрасте от 60 до 74 лет $((64,83 \pm 0,48)$ г.), проходивших амбулаторный этап реабилитации. Методом рандомизации больные были поделены на две группы. Реабилитационный комплекс отличался применением в одной из групп ОПП на нижние конечности.

Результаты. По данным реовазографических исследований у пациентов с ПГА после проведенного реабилитационного комплекса с применением ОПП установлено ускорение гемодинамики ( $<<0,05)$, а по данным артросонографии - уменьшение количества избыточной жидкости в тканях сустава. Также установлено достоверное 
Огляди літератури, оригінальні дослідження, погляд на проблему, ювілеї $(p<0,05)$ уменьшение болевого синдрома, улучшение функциональной активности суставов и физической работоспособности.

Выводы. На основе полученных результатов предложено применение в программе реабилитации больных ПГА объемного пневмопрессинга, который способствует нормализации функционального состояния рефлекторно измененных мышц, активирует местный кровоток и уменьшает венозный стаз. Реабилитационный комплекс с включением ОПП позволяет повысить эффективность проведенных восстановительных мероприятий на амбулаторном этапе реабилитации у больных пожилого возраста с ПГА.

КЛЮЧЕВЫЕ СЛОВА: первичный гонартроз; болевой синдром; реабилитация; объемный пневмопрессинг.

\title{
JOINT PAIN IN PRIMARY GONARTHRITIS IN THE ELDERLY: WAYS TO INCREASE THE EFFECTIVENESS OF REHABILITATION
}

\author{
@T. G. Bakalyuk, I. R. Misula, H. O. Sirant, Yu. V. Zawidniuk, O. Ya. Zyatkovskaya \\ I. Horbachevsky Ternopil State Medical University
}

SUMMARY. The source of pain in osteoarthritis (OA) may be cartilaginous tissue, synovial membrane, subchondral bone and periarticular tissue. Correction of all leading parts of the pathogenesis of OA with medication is insufficient, and ways to increase the effectiveness of treatment of the disease are associated with the use of methods that can affect mechanisms like pathogenesis and sanogenesis. All this is a motive for finding ways to improve the effectiveness of rehabilitation.

The aim of the work is to investigate the effectiveness of using volumetric pneumopressing (VPP) in ambulatory conditions in patients with primary gonarthritis (PGA) in the elderly.

Material and Methods. Clinical observations were performed on 47 patients with PGA aged 60 to 74 years $(64.83 \pm 0.48)$ who underwent an outpatient stage of rehabilitation. By randomization, the patients were divided into two groups. The rehabilitation complex was characterized by application in one of the groups of VPP on the lower extremities.

Results and Discussion. According to reovazographic studies in patients with PGA following a rehabilitation complex using VPP, acceleration of hemodynamics $(p<0.05)$ was determined, and according to artrosonography, reduction of excess fluid in the tissues of the joint. Also, reliable $(p<0.05)$ reduction of pain syndrome, improvement of functional activity of joints and physical capacity have been established.

Conclusions. On the basis of the obtained results, application in the rehabilitation program for patients with PGA volumetric pneumatic pressures, which helps to normalize the functional state of reflex-altered muscles, activates local blood circulation and reduces venous stasis. The rehabilitation complex with the inclusion of VPP allows to increase the efficiency of the rehabilitation measures performed at the outpatient stage of rehabilitation in elderly patients at the PGA.

KEY WORDS: primary gonarthritis; pain syndrome; rehabilitation; volume pneumatic pressuring.

Отримано 25.02.2018 